\title{
Aplikasi Monitoring Dalam Evaluasi Akademik Untuk Penilaian Kinerja Guru Berbasis Web di SDN 001 Nongsa
}

\author{
Didin Setyawan *1 Agus Suryadi², Dhini Eka Nurbaiti ${ }^{3}$ \\ 1,2Jln, Teuku Umar Lubuk Baja Kota Batam Kepulauan Riau 29432. Telp. (0778) \\ 425391. \\ ${ }^{3}$ Program Studi Teknik Informatika, Universitas Ibnu Sina, Batam \\ e-mail: ${ }^{* 1}$ didinsetyawan@uis.ac.id, ${ }^{2}$ agus@uis.ac.id, ${ }^{3} 1610128262131 @$ uis.ac.id
}

\begin{abstract}
Abstrak
Perancangan Aplikasi Monitoring dalam Evaluasi Akademik untuk Penilaian Kinerja Guru Berbasis Web di SDN 001 Nongsa ini merupakan aplikasi pendukung kinerja pihak istansi terkait. Kurangnya pendataan dan tidak adanya aplikasi pendukung serta data yang masih disimpan dalam bentuk arsip maupun komputer secara manual. Sistem ini dirancang berbasis website dengan menggunakan bahasa pemprograman html, css dan database MySQL. Sedangkan pengembangan sistem penelitian menggunakan metode RAD (Rapid Application Development) dengan tahapan requirements, workshop design, dan implementation. Aplikasi ini berfungsi sebagai sarana untuk mengetahui teknik pelaksanaan monitoring dalam evaluasi akademik terhadap kinerja guru. Dengan adanya sistem yang dirancang ini pihak instansi akan lebih mudah untuk melakukan pelaksanaan monitoring dalam evaluasi akademik terhadap kinerja guru. Serta kebutuhan pembuatan laporan penilaian kinerja guru.
\end{abstract}

Kata kunci- Penilaian Kinerja Guru, Monitoring, Web, RAD (Rapid Application Development)

\begin{abstract}
The design of the Monitoring Application in Academic Evaluation for Web-Based Teacher Performance Assessment at SDN 001 Nongsa is an application to support the performance of the relevant agencies. Lack of data collection and the absence of supporting applications as well as data that is still stored in archives and computers manually. This system is designed based on website using html, css programming language and MySQL database. While the development of the research system uses the RAD (Rapid Application Development) method with the stages of requirements, workshop design, and implementation. This application serves as a means to determine the implementation of monitoring techniques in academic evaluation of teacher performance. With this system designed, the agency will find it easier to carry out monitoring in the academic evaluation of teacher performance. As well as the need for making teacher performance appraisal reports.
\end{abstract}

Keywords - Teacher Performance Assessment, Monitoring, Web, RAD (Rapid Application Development)

\section{PENDAHULUAN}

Guru mempunyai fungsi dan peran yang sangat strategis dalam pembangunan bidang pendidikan, dan oleh karena itu perlu dikembangkan sebagai profesi yang 
bermartabat. Undang-Undang No. 14 tahun 2005 tentang Guru dan Dosen Pasal 4 menegaskan bahwa guru sebagai agen pembelajaran berfungsi untuk meningkatkan mutu pendidikan nasional. Untuk dapat melaksanakan fungsinya dengan baik, guru wajib memiliki syarat tertentu, salah satu diantaranya adalah kompetensi. Kompetensi guru merupakan seperangkat penguasaan kemampuan yang harus ada dalam diri guru agar dapat mewujudkan kinerja secara tepat dan efektif (Undang-Undang Republik Indonesia Nomor 14 Tahun 2005 Tentang Guru dan Dosen).

SDN 001 Nongsa adalah pelaksana teknis operasional pendidikan Dinas Pendidikan Kota Batam dalam pelaksanaan pembinaan, pengawasan dan penilaian kegiatan penyelenggaraan pendidikan. Sebagai penilai dan penyelenggara kegiatan penyelenggaraan pendidikan, Kepala SDN 001 Nongsa yang membawahi kurang lebihnya 20 tenaga pendidik, mempunyai tugas dan wewenang untuk mengawasi dan melaksanakan jalannya penilaian kinerja guru dan sasaran kerja pegawai di sekolah yang menjadi wewenangnya.

Sebagai pengawas dalam pelaksanaan PKG, SDN 001 Nongsa menjumpai beberapa hambatan. Hambatan nyata yang harus mereka hadapi adalah besarnya jumlah guru yang harus mereka awasi. Selain itu, aplikasi PKG yang masih menggunakan program aplikasi spreadsheet juga menjadi penghambat lain dalam penyelesaian PKG. Hambatan itu muncul karena aplikasi yang ada mempunyai akurasi dan risk management menjumpai error dalam proses penilaian sangatlah besar. Hal ini tentunya menjadi masalah, mengingat metode pengajuan PKG masih menggunakan hardcopy, sehingga, apabila PKG yang diajukan tidak sesuai dengan ketentuan, pejabat penilai harus mengulangi proses dan revisi.

Melihat fakta diatas, maka diperlukan sistem yang baik dan dapat menghasilkan informasi yang akurat, relevan dan juga tepat waktu. Sistem PKG berbasis website diharapkan menjadi solusi yang dapat membantu SDN 001 Nongsa dalam melakukan dan mengawasi penilaian, sehingga proses penilaian menjadi cepat, relevan dan tepat sasaran

Maka dengan adanya aplikasi penilaian kinerja guru berbasis web yang baru akan nantinya dapat menghasilkan sistem penilaian dengan prosedur yang lebih efektif dan efisien serta proses rekapitulasi dapat dilakukan dengan mudah dan memiliki tingkat validasi yang tinggi.

\section{METODE PENELITIAN}

\subsection{Metode System Development Life Cycle (SDLC)}

Dalam fase pengembangan sistem penulis menggunakan System Development Life Cycle (SDLC) dengan pendekatan waterfall yang terdiri atas beberapa tahapan aliran aktifitas yang berjalan satu arah dari awal sampai akhir pengembangan proyek pengembangan sistem.

System Development Life Cycle (SDLC) merupakan siklus pengembangan sistem dengan beberapa proses secara bertahap di dalam merancang dan mengembangkan sistem. SDLC memiliki tahapan dalam pengembangan sistem yaitu, perencanaan, analisis, perancangan, implementasi, dan perawatan (maintenance) (Dwina Admella Yudhanti, dkk, 2019:323).

System Development Life Cycle (SDLC) memiliki beberapa model dalam penerapan tahapan prosesnya. Salah satu pengembangan dari SDLC adalah model RAD (Rapid Application Development). Definisi metode RAD (Rapid Application 
Development) menurut Pressman (dalam jurnal Aini dkk, 2019), yaitu suatu metode yang digunakan dalam pengembangan software tambahan dimana siklus pengembangannya relative singkat.

Adapun tahapan yang ada dalam membangun rekayasa perangkat lunak itu sendiri adalah sebagai berikut:

\subsubsection{Perencanaan (planning)}

Merupakan tahap awal dari perancangan sistem, tahap ini bertujuan untuk mengidentifikasi dan memprioritaskan sistem informasi apa yang akan dikembangkan, sasaran-sasaran yang ingin dicapai, jangka waktu pelaksanaan serta mempertimbangkandana yang tersedia dan siapa yang melaksanakan.

\subsubsection{Analisis (Analysis)}

Analisis sistem adalah penelitian atas sistem yang telah ada dengan tujuan untuk merancang sistem baru atau memperbaharui sistem yang sudah ada.

\subsubsection{Perancangan (Design)}

Perancangan sistem adalah penentuan proses dan data yang diperlukan oleh system baru. Jika system ini berbasis komputer, rancangan dapat menyertakan spesifikasi jenis peralatan yang akan digunakan.

\subsubsection{Implementasi (implementation)}

Implementasi merupakan kegiatan memperoleh dan mengintegrasikan sumber daya fisik dan konseptual yang menghasilkan suatu sistem yang bekerja. Pada tahapan ini dilakukan beberapa hal yaitu: Coding, Testing, Instalasi.

\subsubsection{Perawatan (maintenance)}

Selama pengguna menggunakan sistem, berbagai modifikasi dibuat sehingga sistem terus memberikan dukungan yang diperlukan. Modifikasi ini disebut dengan pemeliharaan sistem.

\subsection{RAD (Rapid Application Development)}

RAD (Rapid Application Development) merupakan metodologi yang menekankan pada siklus pembangunan pendek, singkat, dan cepat. Waktu yang singkat adalah batasan yang penting untuk model ini. Rapid Application Development menggunakan metode iteratif (berulang) dalam mengembangkan sitem dimana working model (model kerja) sistem dikonstruksikan di awal tahap pengembangan dengan tujuan menetapkan kebutuhan (requirement) pengguna. RAD mempunyai kemampuan untuk menggunakan kembali komponen yang ada (reusable object) sehingga pengembang tidak perlu membuat dari lagi dan waktu yang lebih singkat. RAD memiliki tahapantahapan sebagai berikut (Kendall, dalam jurnal Pusparini dkk, 2017).

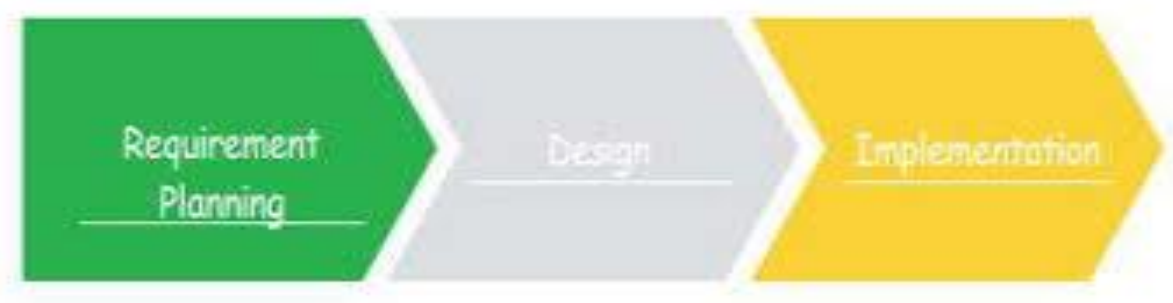

Gambar 2.1 Model RAD (Rapid Application Development) 
Tahapan yang ada pada model RAD dapat dijabar kan sebagai berikut :

1. Rencana Kebutuhan (Requirement Planning)

Pada tahap awal, pemesan bertemu dengan pengembang sistem dan melakukan pendefinisian terhadap ruang lingkup sistem yang akan dibangun. Pada penelitian ini sistem yang akan dibuat adalah sistem ensiklopedia. Selanjutnya dengan melakukan analisis terhadap masalah dan kebutuhan sistem serta jalan keluarnya. Misalnya, bagaimana cara user melakukan penambahan informasi baru serta bagaimana agar informasi yang diinginkan user dapat dengan mudah ditemukan serta tingkatan user yang diperlukan dalam menjalankan sistem.

2. Proses Desain (Design Workshop)

Pada tahapan berikutnya dilakukan proses desain terhadap sistem yang akan dikembangkan. Kemudian desain tersebut dilanjutkan oleh programmer dengan pembuatan prototype dari aplikasi yang dimaksud dan menampilkan kepada user hasilnya dengan cepat. Pada selang waktu tersebut, user bisa memberikan tanggapan akan sistem yang sudah dikembangkan untuk selanjutnya dilakukan perbaikanperbaikan. Dengan demikian proses pengembangan sistem menjadi lebih cepat.

3. Implementasi (Implementation)

Selanjutnya programmer mengembangkan prototype menjadi suatu program. Setelah sistem selesai secara keseluruhan, maka dilakukan proses pengujian terhadap program tersebut apakah terdapat kesalahan atau tidak sebelum diaplikasikan pada suatu organisasi. Jika proses tersebut telah dilakukan maka akan dihasilkan sistem yang lengkap sesuai dengan desain awal.

\section{HASIL DAN PEMBAHASAN}

\subsection{Analisa Sistem}

Penelitian dan pengumpulan data pada sistem yang sedang berjalan dengan tujuan mendapatkan data secara lengkap untuk dapat merancang sistem yang baru atau sistem yang akan diperbaharui dari sistem yang sedang berjalan. Dengan data yang diperoleh maka akan dapat diimplementasikan pada sistem yang nantinya akan dibuat.

\subsubsection{Analisa Kebutuhan Sistem}

Berdasarkan observasi yang telah dilakukan di SDN 001 Nongsa, maka diperoleh kebutuhan sistem yang dibutuhkan, antara lain sebagai berikut:

1. Admin bertugas untuk untuk menginput data sekolah, data guru, data penilai, mengedit data, menghapus data. Laporan hasil penilaian

2. Tim penilai dapat menginput data guru yang akan dinilai dan diberi akses untuk melakukan penilaian terhadap guru.

3. Kepala sekolah, dapat melihat laporan data penilaian kinerja guru

Berdasarkan Aliran Sistem Informasi Lama dapat disimpulkan bahwa dibutuhkan adanya database baru untuk memenuhi kebutuhan sistem pada Aplikasi Monitoring dan Evaluasi Akademik Untuk Penilaian Kinerja Guru Berbasis Web di SDN 001 Nongsa yang fitur-fitur tersebut dapat dilihat pada tabel dibawah ini. 
Tabel 3.1 Kebutuhan Sistem

\begin{tabular}{|c|l|l|}
\hline No & Fitur & \multicolumn{1}{|c|}{ Keterangan } \\
\hline 1 & Login & $\begin{array}{l}\text { Berfungsi sebagai hak akses untuk } \\
\text { membedakan halaman apa saja yang boleh } \\
\text { diakses oleh guru/pengguna dan halaman } \\
\text { admin. }\end{array}$ \\
\hline 2 & Data Sekolah & $\begin{array}{l}\text { Berfungsi untuk menampilkan data sekolah } \\
\text { terdapat informasi identitas sekolah, data guru, } \\
\text { dan periode penilaian. }\end{array}$ \\
\hline 3 & Penilaian & $\begin{array}{l}\text { Berfungsi untuk menampilkan data penilaian, } \\
\text { dan penilaian yang akan dilakukan terhadap } \\
\text { kinerja guru di SDN 001 Nongsa. }\end{array}$ \\
\hline 4 & Data User & $\begin{array}{l}\text { Berfungsi untuk menampilkan menampilkan } \\
\text { seluruh pengguna serta level dari masing- } \\
\text { masing pengguna yang telah ditambahkan ke } \\
\text { dalam aplikasi tersebut.. }\end{array}$ \\
\hline
\end{tabular}

\subsection{Perancangan Sistem}

Peracangan sistem merupakan tahapan selanjutnya setelah menganalisa sistem yang dibutuhkan serta mendapatkan gambaran dengan jelas tentang apa yang akan dibuat. Untuk mencapai harapan pembuatan aplikasi penilaian kinerja guru di SDN 001 Nongsa, pembuatan aplikasi ini akan digambarkan menggunakan usecase digram, rancangan database dan relasi database.

\subsubsection{Usecase Diagram}

Pada tahap ini peneliti akan menunjukan usulan alur proses sistem yang akan dibuat dengan menunjukan fungsi-fungsi sistem pengguna secara logika dengan menggunakan usecase diagram, yakni sebagai berikut:

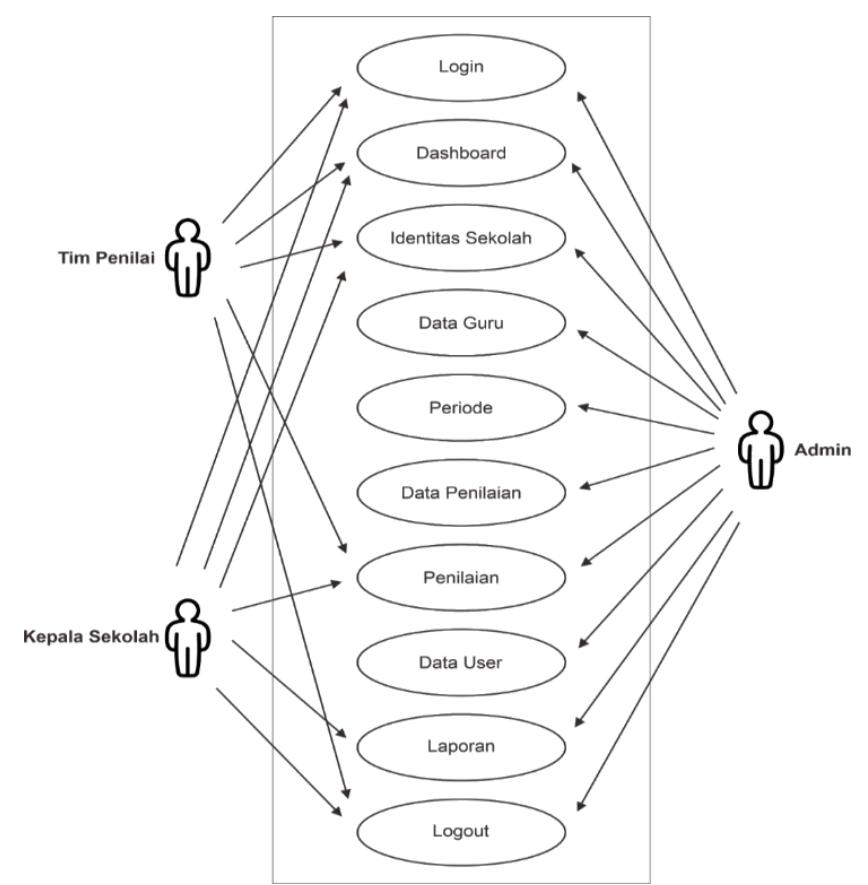

Gambar 3.1 Usecase Diagram 


\subsection{Implementasi}

Berdasarkan perancangan sistem yang telah dibuat sebelumnya, pada implementasi ini akan menyertakan gambar dari Aplikasi Monitoring dalam Evaluasi Akademik untuk Penilaian Kinerja Guru Berbasis Web di SDN 001 Nongsa yang telah dijalankan pada Web Browser yaitu Google Chrome.

3.3.1 Tampilan Aplikasi

1. Pada halaman login ada tiga user yang dapat mengakases login, yaitu admin, tim penilai serta kepala sekolah. Dan setiap user memiliki hak akses yang berbeda.

\section{(2) Monitoring Penilaian Kinerja Guru}

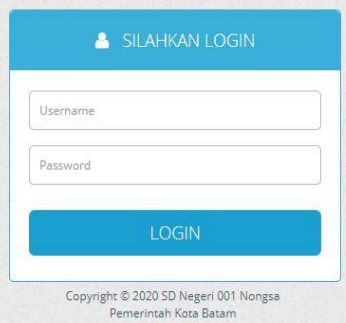

\section{Gambar 3.2 Tampilan Login}

2. Langkah-langkah yang harus dilakukan pada halaman login adalah:

1. Memasukkan user login yang telah didaftarkan.

2. Memasukkan password sebagai kata kunci untuk masuk ke halaman dashboard aplikasi.

3. Klik login, maka akan tampil halaman dashboard sebagai berikut:

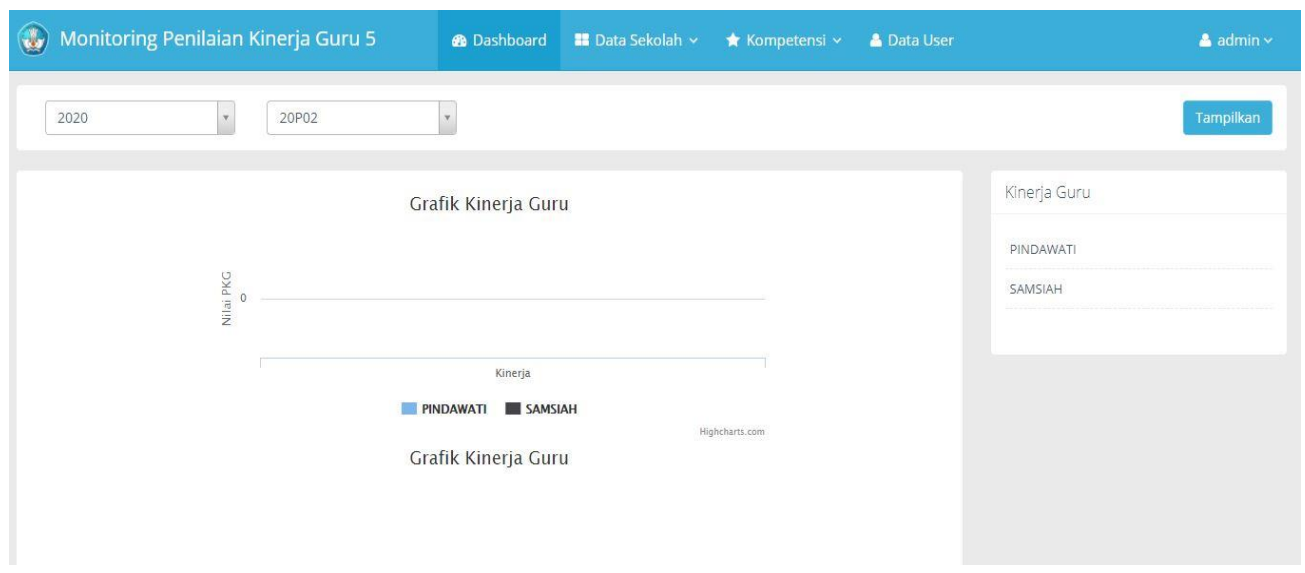

Gambar 3.3 Tampilan Dashboard Guru

Pada halaman dashboard terdapat menu kerja guru diataranya data sekolah, kompetensi, dan data user. Untuk lebih rincinya dapat dilihat sebagai berikut: 
1. Tampilan data sekolah berfungsi untuk menampilkan identitas sekolah, data guru dan periode penilaian. Untuk tampilan dapat dilihat dibawah ini:

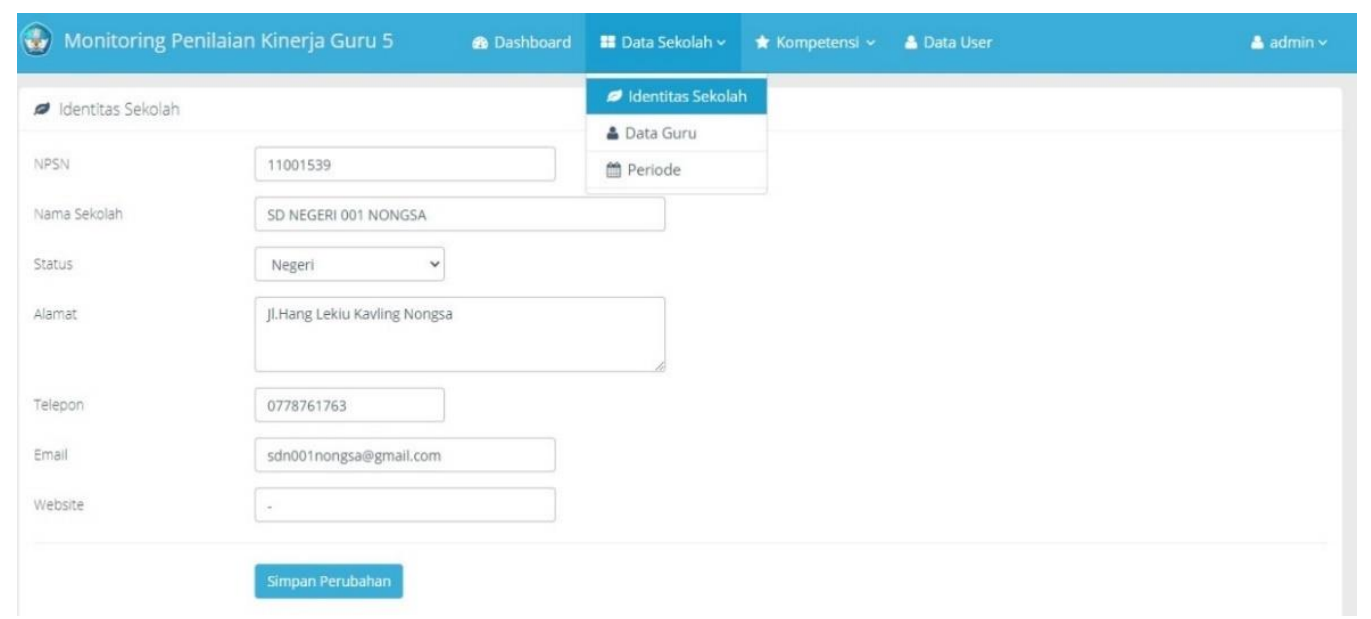

Gambar 3.4 Tampilan Menu Data Sekolah

2. Tampilan menu kompetensi untuk melihat data penilaian dan penilaian yang ada di SDN 001 Nongsa. Untuk tampilan dapat dilihat dibawah ini:

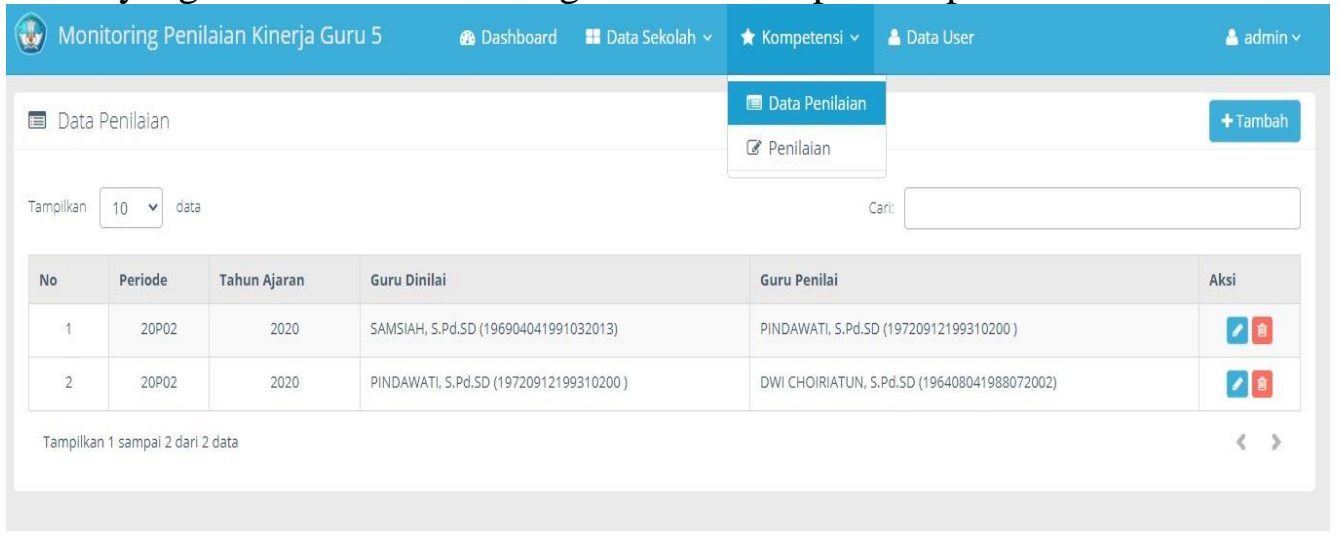

Gambar 3.5 Tampilan Menu Kompetensi

3. Tampilan menu data user untuk menampilkan seluruh pengguna serta level dari masing-masing pengguna yang telah ditambahkan ke dalam aplikasi tersebut. Untuk tampilan dapat dilihat dibawah ini: 


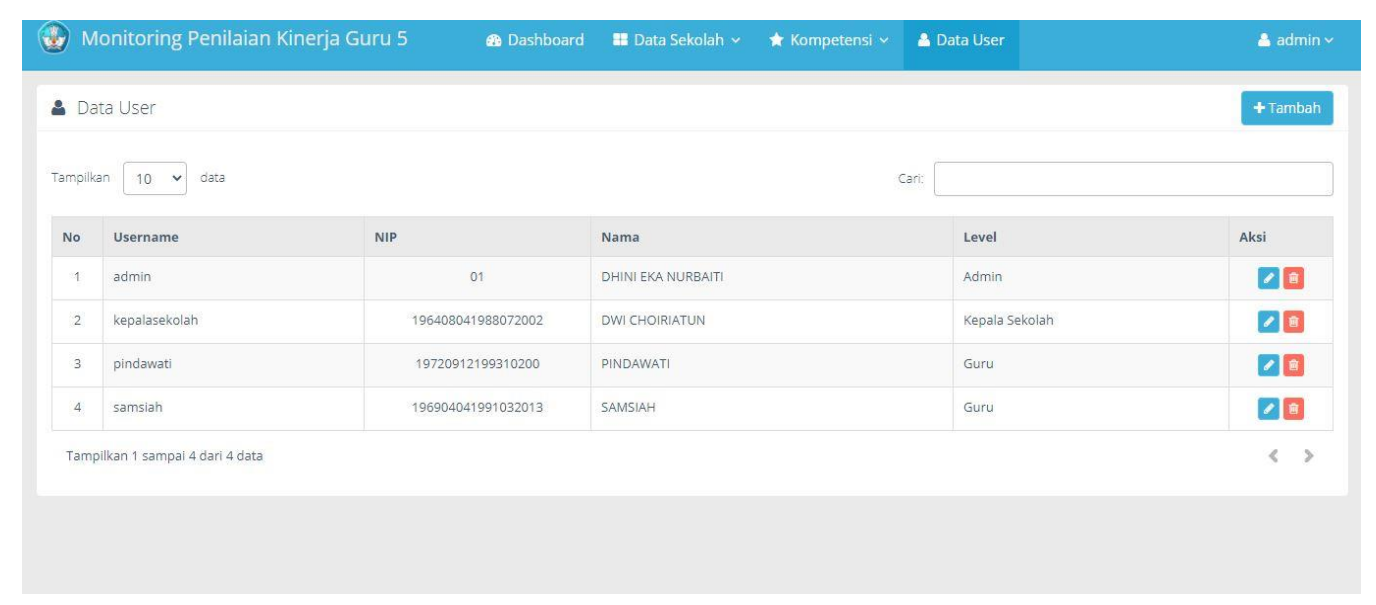

Gambar 3.6 Tampilan Menu Data User

\subsection{Test atau Pengujian}

Pada tahap pengujian, penulis menggunakan spesifikasi perangkat keras dan perangkat lunak sebagai berikut:

1. Spesifikasi Perangkat Keras

a. Motherboard

: Intel

b. Processor : Intel Core i7-855U CPU @ 1.8Ghz

c. Harddisk :1 TB

d. RAM

e. Keyboard : 8 GB (7.88 GB Usable)

f. Mouse :Standard

2. Spesifikasi Perangkat Lunak

a. Sistem Operasi

b. Web Browser

: Windows 10 Pro 64-bit

Uji coba dari Aplikasi Monitoring dalam Evaluasi Akademik untuk Penilaian Kinerja Guru Berbasis Web di SDN 001 Nongsa diuji dengan model teknik black box. Pengujian black box digunakan untuk menguji fungsi-fungsi khusus dari perangkat lunak yang dirancang. Teknik pengujian black box adalah suatu pengujian yang dilakukan untuk mengamati hasil dari eksekusi pada software tersebut. Pengamatan hasil ini melalui data uji dan memeriksa fungsional dari perangkat lunak itu sendiri.

Untuk pengujian menggunakan teknik black box dapat ditampilkan sebagai berikut.

Tabel 3.2 Pengujian Black Box

\begin{tabular}{|c|c|c|c|c|}
\hline No & Modul & Tes yang dilakukan & $\begin{array}{l}\text { Hasil yang } \\
\text { diharapkan }\end{array}$ & $\begin{array}{l}\text { Hasil } \\
\text { Akhir }\end{array}$ \\
\hline 1 & Login & $\begin{array}{l}\text { Login ke sisi Admin dan } \\
\text { Guru }\end{array}$ & $\begin{array}{l}\text { Tampilan halaman } \\
\text { Admin dan Guru }\end{array}$ & $\mathrm{OK}$ \\
\hline 2 & Input & $\begin{array}{l}\text { Menginput data identitas } \\
\text { sekolah, data guru, dan } \\
\text { periode }\end{array}$ & $\begin{array}{l}\text { Tampilan data yang } \\
\text { baru ditambahkan }\end{array}$ & $\mathrm{OK}$ \\
\hline 3 & Hapus & $\begin{array}{l}\text { Menghapus data identitas } \\
\text { sekolah, data guru, dan }\end{array}$ & $\begin{array}{l}\text { Data yang dipilih telah } \\
\text { terhapus }\end{array}$ & $\mathrm{OK}$ \\
\hline
\end{tabular}




\begin{tabular}{|c|c|c|c|c|}
\hline & & periode & & \\
\hline 4 & Edit & $\begin{array}{l}\text { Merubah data identitas } \\
\text { sekolah, data guru, dan } \\
\text { periode }\end{array}$ & $\begin{array}{l}\text { Perubahan data yang } \\
\text { dipilih }\end{array}$ & $\mathrm{OK}$ \\
\hline 5 & Pencarian & $\begin{array}{l}\text { Memasukkan keyword yang } \\
\text { dicari }\end{array}$ & $\begin{array}{l}\text { Menampilkan data } \\
\text { yang dicari }\end{array}$ & $\mathrm{OK}$ \\
\hline 6 & Print & $\begin{array}{l}\text { Melakukan print data guru } \\
\text { dari hasil penilaian menjadi } \\
\text { softcopy maupun hardcopy }\end{array}$ & $\begin{array}{l}\text { Menampilkan data } \\
\text { guru dari hasil peniaian } \\
\text { menjadi softcopy } \\
\text { maupun hardcopy }\end{array}$ & $\mathrm{OK}$ \\
\hline 7 & Keamanan & $\begin{array}{l}\text { Mengakses secara langsung } \\
\text { halaman yang diinginkan }\end{array}$ & Tampil halaman login & $\mathrm{OK}$ \\
\hline
\end{tabular}

\section{KESIMPULAN}

Mengacu pada rumusan masalah dan tujuan penelitian yang terdapat pada pada bab satu dan dilanjutkan dengan implementasi pada bab 4 maka dapat ditarik beberapa kesimpulan diantaranya:

1. Perancangan Aplikasi Monitoring dalam Evaluasi Akademik Untuk Penilaian Kinerja Guru Berbasis Web di SDN 001 Nongsa dirancang dengan menggunakan bootstrap, html dan MySql sebagai database. Maka aplikasi ini dapat dijalankan pada multiplatform dan sangat memungkinkan untuk dikembangkan kedepan.

2. Dengan menggunakan Aplikasi Monitoring dalam Evaluasi Akademik Untuk Penilaian Kinerja Guru Berbasis Web di SDN 001 Nongsa menjadi lebih cepat dan efektif

\section{SARAN}

Setelah merancang Aplikasi Monitoring dalam Evaluasi Akademik Untuk Penilaian Kinerja Guru Berbasis Web di SDN 001, ada beberapa saran yang harus diterapkan guna pengembangan sistem ini lebih lanjut:

1. Aplikasi yang telah dibuat diharapkan dapat diterapkan di instansi terkait.

2. Membuat sistem yang mampu menyimpan data rekam penilaian kinerja guru dengan menggunakan replikasi data di client server.

3. Desain aplikasi dapat dikembangkan lagi dengan desain yang user interfacenya lebih menarik.

4. Mengembangkan sistem yang mampu menyimpan data monitoring penilaian kinerja guru sesuai dengan penilaian yang digunakan di SDN 001 Nongsa.

\section{UCAPAN TERIMA KASIH}

Terima kasih kepada Allah SWT, saudara dan keluarga saya atas do'a dan dukungannya yang telah diberikan. Tak lupa pula teman, sahabat yang dalam masa perkuliahan selalu memberikan bantuan moril dan materil maupun dukungan yang luar biasa hingga saya bisa sampai pada titik penyelesaian tugas akhir.

DAFTAR PUSTAKA 
[1] Afnoto, M. Y., \& Nugrahaningsih, D. (2017). Sistem Informasi Data Alumni Politeknik Muhammadiyah Pekalongan Berbasis Web. Jurnal Surya Informatika, 4(1).

[2] Aini, N., Wicaksono, S. A., \& Arwani, I. (2019). Pembangunan Sistem Informasi Perpustakaan Berbasis Web menggunakan Metode Rapid Application Development (RAD)(Studi pada: SMK Negeri 11 Malang). Jurnal Pengembangan Teknologi Informasi dan Ilmu Komputer e-ISSN, 2548, 964X.

[3] Aprilia, K. (2019). Rancang Bangun On/Off Lampu Ruangan Menggunakan Kendali RFID Berbasis Mikrokontroller (Doctoral dissertation, POLITEKNIK NEGERI SRIWIJAYA).

[4] Destiningrum, M., \& Adrian, Q. J. (2017). Sistem Informasi Penjadwalan Dokter Berbassis Web Dengan Menggunakan Framework Codeigniter (Studi Kasus: Rumah Sakit Yukum Medical Centre). Jurnal Teknoinfo, 11(2), 30-37.

[5] Dwina Admella Yudhanti., Eva Faja Ripanti., \& Anggi Perwitasari. (2019). Knowledge Management System Konservasi Hutan Tanaman Mangrove. JEPIN (Jurnal Edukasi dan Penelitian Informatika). 5. 321-328.

[6] Fabiyanto, A. R., Mursityo, Y. T., \& Pramono, D. (2019). Pengembangan Sistem Informasi Penilaian Kinerja Guru Menggunakan Metode Rational Unified Process (RUP) Berbasis Web (Studi Pada SD Negeri Prigen 1). Jurnal Pengembangan Teknologi Informasi dan Ilmu Komputer e-ISSN, 2548, 964X.

[7] Handayani, T., Taher, Y. S. B., Usman, A. H., \& Ambarita, A. (2019). Aplikasi Pemeriksaan Biaya Instalasi Tegangan Listrik Rendah Berbasis Web pada PT. PPILN Maluku Utara. IJIS-Indonesian Journal On Information System, 4(1).

[8] Heriyanto, Y. (2018). Perancangan Sistem Informasi Rental Mobil Berbasis Web Pada PT. APM Rent Car. Jurnal Intra Tech, 2(2), 64-77.

[9] Herliana, A., \& Rasyid, P. M. (2016). Sistem Informasi monitoring pengembangan software pada tahap development berbasis web. Jurnal Informatika, 3(1).

[10] Ibrahim, D. (2020). ANALISA DAN PERANCANGAN SISTEM INFORMASI PENILAIAN KINERJA GURU BERBASIS WEBSITE MENGGUNAKAN METODE SIMPLE ADDITIVE WEIGHTING (SAW)(STUDI KASUS: SMA AL KAMAL JAKARTA). JUSIBI (Jurnal Sistem Informasi dan Bisnis Digital), 2(1).

[11] Koyuko, H., Sinsuw, A. A., \& Najoan, X. B. (2016). Perancangan Aplikasi Monitoring Pemadaman Listrik Berbasis Android Studi kasus PT. PLN area Manado. Jurnal Teknik Informatika, 9(1).

[11]Lela Komalasari, I. (2019). KOMPUTERISASI AKUNTANSI PENGGAJIAN KARYAWAN PADA PT. SUMMIT ADYAWINSA INDONESIA BERBASIS WEB. Jurnal Interkom, 13(4).

[12]Lutfi, A. (2017). SISTEM INFORMASI AKADEMIK MADRASAH ALIYAH SALAFIYAH SYAFI'IYAH MENGGUNAKAN PHP DAN MYSQL. Jurnal AiTech, 3(2), 104-112. 
[13] Multazam, M., Samsumar, L. D., \& Arwidiyarti, D. (2018). Rancang Bangun Sistem Informasi Evaluasi Kinerja Dosen Dalam Perkuliahan Untuk Meningkatkan Kualitas Proses Pembelajaran. Jurnal Teknologi Informasi dan Komunikasi, 7(2), 74-87.

[14] Mustofa, M. (2019). PERANCANGAN SISTEM PENDUKUNG KEPUTUSAN PENILAIAN KINERJA GURU MENGGUNAKAN METODE PROFILE MATCHING STUDI KASUS DI MTS NEGERI BRANGSONG. E-Bisnis: Jurnal Ilmiah Ekonomi dan Bisnis, 12(2), 29-34.

[15] Nababan, B. A., Budiawan, R., \& Rosely, E. (2018). Aplikasi Monitoring Dan Penilaian Guru (Studi Kasus Smpk 4 Penabur Bandung). eProceedings of Applied Science, 4(1).

[16] Pattianakotta, A., Sinsuw, A. A., \& Lumenta, A. S. (2015). Sistem Informasi Arsip Dokumen Kantor Pelayanan Kekayaan Negara Dan Lelang Manado. Jurnal Teknik Elektro dan Komputer, 4(7), 8-14.

[17] Purbasari, Y. (2017). Rancang Bangun Aplikasi Penjualan Dan Persediaan Obat Pada Apotek Merben Di Kota Prabumulih.jsk (Jurnal Sistem Informasi dan Komputerisasi Akuntansi), 1(1), 81-88.

[18] Pusparini, E. S., Najoan, M. E., \& Najoan, X. B. (2017). Sistem Informasi Akademik Berbasis Mobile Web menggunakan Pendekatan Metodologi RAD (Studi Kasus: Universitas Sam ratulangi). Jurnal Teknik Elektro dan Komputer, 6(4), 182-193.

[19]Ridlo, I. A. (2017). Panduan Pembuatan Flowchart. Fakultas Kesehatan Masyarakat, Departemen Administrasi Dan Kebijakan Kesehatan.

[20]Risanty, R. D., \& Sopiyan, A. (2017). Pembuatan Aplikasi Kuesioner Evaluasi Belajar Mengajar Menggunakan Bot Telegram Pada Fakultas Teknik Universitas Muhammadiyah Jakarta (FT-UMJ) Dengan Metode Polling. Prosiding Semnastek.

[21] Rizan, O., \& Hamidah, H. (2016). RANCANGAN APLIKASI MONITORING KAMERA CCTV UNTUK PERANGKAT MOBILE BERBASIS ANDROID. Jurnal TI Atma Luhur, 3(1), 45-52. 